\title{
Cattle management practices and milk production on mixed smallholder organic pineapple farms in Central Uganda
}

\author{
S. Nalubwama ${ }^{1,2} \cdot$ F. Kabi $^{2} \cdot$ M. Vaarst ${ }^{3}$ - G. Smolders ${ }^{4}$ - M. Kiggundu ${ }^{2}$
}

Received: 13 January 2016 / Accepted: 2 August 2016

(C) Springer Science+Business Media Dordrecht 2016

\begin{abstract}
A longitudinal study to assess animal management practices and milk production was conducted for a period of 12 months on 30 smallholder farms keeping dairy cattle and certified organic pineapple production in Luwero and Kayunga districts, based on questionnaire and on-farm collected data. Farm sizes were $9.3 \pm 6.7$ acres in tethering system and $4.3 \pm 2.6$ acres in zero-grazing. Fifty-four percent of the zero-grazing herds had animal housing facilities. All farmers in tethering system kept cows on earthen floors and calves without bedding. Hygiene level in existing farms was low. Majority of calves were fed once a day by restricted suckling (77\%). Seventy-four percent of tethered cows were only fed on natural grass, while cows under zero-grazing system had a more diversified diet but with $82 \%$ feeding mainly Napier grass. Most farms $(87 \%)$ used bulls for breeding. Milk production was higher $(P<0.05)$ in zero-grazing $(6.5 \mathrm{~L} /$ cow/day $)$ than tethering system, and higher $(P<0.05)$ for HolsteinFriesian crossbred cows $(5.2 \mathrm{~L} / \mathrm{cow} /$ day $)$ than local breed cows $(2.6 \mathrm{~L} /$ cow/day). Less than $1 \mathrm{~L}$ of milk per farm per day on average was sold. Disease treatments were exclusively for helminths, East Coast fever, and trypanasomiasis. Spraying of ticks and deworming were important control measures of vector-borne diseases. There is potential to develop
\end{abstract}

S. Nalubwama

drnalubwama@gmail.com

1 Department of Livestock and Industrial Resources, Makerere University, P.O. Box 7062, Kampala, Uganda

2 Department of Agricultural Production, Makerere University, P.O. Box 7062, Kampala, Uganda

3 Department of Animal Science, Aarhus University, P.O. Box 50, DK-8830 Tjele, Denmark

4 OrgANIMprove, Karveel 13-03, 8231 AT Lelystad, The Netherlands alternative feed resources for dairy cattle and biorational pesticides for control and treatment of vector-borne diseases.

Keywords Cattle management $\cdot$ Milk production $\cdot$ Organic

\section{Introduction}

By 2010, Uganda had about 200,000 certified organic farmers with about 230,000 ha of land (FiBL and IFOAM 2013; Willer and Lernoud 2015). Currently, over 400,000 organic farmers with 350,000 ha are certified covering $2 \%$ of agricultural land (Rukundo 2014). Great potential for growth of organic agriculture continues to exist in Uganda due to its comparative advantage of good weather and low inorganic fertilizer use (Zenere 2014).

In a recent study in Luwero and Kayunga districts in Uganda, farms with certified organic pineapple production were found to be diversified with various livestock and crops (Nalubwama et al. 2014). The integration of crop and livestock production is considered to be a key pathway to improved productivity, efficiency, and sustainability (Powell et al. 2004). Livestock production contributes to nutrient balance of the whole farming system, which is very relevant for organic agriculture where the system approach is emphasized (Henning 1998). Furthermore, potential to market organic animal products has recently been identified in local and regional markets (Anecho 2015). However, studies indicate that organic farmers in Uganda continue to rear livestock without adherence to organic principals and standards (Kiggundu et al. 2014; Nalubwama et al. 2011). This has been attributed to various livestock production challenges faced in smallholder farming systems such as endemic animal diseases and pests which are still controlled using conventional methods; insufficient supply of certified organic feeds; and limited land and 
scanty knowledge on improved farm management practices (Nalubwama et al. 2014; Odhong et al. 2015).

Documented information and in-depth understanding of livestock production and conditions under which smallholder organic farms operate in Uganda is scanty. This calls for recommendations for improvements for better management of dairy cows and future adoption of organic dairy farming as specified by East Africa Organic Product (EAOP) Standards (EAOPS 2007). The aim of this article was to assess cattle management practices and conditions on smallholder certified organic pineapple farms with dairy cattle and their potential effects on milk production and animal health.

\section{Materials and methods}

\section{Study area and sampling methods}

The study was conducted in Luwero and Kayunga districts in central Uganda. Both districts are major areas for organic pineapple production (FIT 2006). Kayunga district is situated about $74 \mathrm{~km}$ east of Kampala and Luwero district is located about $75 \mathrm{~km}$ north of Kampala. The rainfall pattern is bimodal with the rainy seasons in March to May and October to November.

A longitudinal survey was conducted for a period of 12 months (August 2013-July 2014) to gather data from 30 mixed smallholder certified organic pineapple farms. The farms were purposefully selected from a larger sample in the previous study based on certified organic pineapple production and presence of at least one dairy cow (Nalubwama et al. 2014). Eleven zero-grazing farms from the previous study were included, and random sampling was used to select the remaining 19 farms from a group of 61 farms with tethering system.

\section{Data collection}

A baseline study to asses land size, land use, cropping, livestock management practices, challenges as well as coping strategies and farmers' perceptions to organic livestock production was conducted 2 months before onset of milk recordings. In addition to following up on all lactating cows, in-calf cows which were expected to calve during the study period were also monitored. A total of 56 cows were included in the study, and out of these, 44 cows had milk recordings taken. One farm was followed without any lactating cow because the only cow found at that farm did not give birth as expected. Milk production (milk consumed at home, milk given away, milk sold and its prices, and milk fed to calves), calving, and disease treatments were recorded by farmers on pre-formatted record sheets. Two trained field assistants crosschecked and reinforced record keeping, and the authors visited each farm every month.

\section{Data analysis}

Questionnaire data was analyzed using SPSS software (Statistical Package for Social Sciences for Windows, version 16.0) for descriptive statistics. $t$ test was used to assess differences in size of land and reproductive parameters of dairy cattle in the two management systems. Farmers' perceptions were ranked according to their Likert average scale values. Estimation of effects of known fixed factors (breed, management system, and season) on milk production was analyzed using PROC MIXED Models of Statistical Analysis System (SAS 9.1). In the calculations of the lactation curves, 41 cows with a known calving date were included. The average milk yield per 2 weeks period was calculated by the integer part of ((milking date - calving date) $/ 14)+1$. To calculate the number of Tropical Livestock Units (TLU), the different categories of cattle and other livestock were converted as 1 cow or bull $=1.2 \mathrm{TLU}, 1$ heifer or steer $=0.7,1$ calf $=0.3,1$ sheep or goat $=0.15,1$ chicken or duck $=0.01$, and $1 \mathrm{pig}=0.2 \mathrm{TLU}$ (conversion factors were based on livestock demographic structure and mean weights according to Jahnke (1982)).

\section{Results}

\section{Herd structure}

Majority of households owned one or two dairy cows, and $7 \%$ of the farms owned a bull as presented in Table 1. Apart from cattle, the farms also kept other livestock including goats, pigs, chickens, and ducks. Tethering systems had a total of 6.81 TLU, while zero-grazing systems had 2.36 TLU on average.

Average age at first calving was relatively lower $(P<0.001)$ for cows under zero-grazing systems compared to cows under tethering systems as presented in Table 2 . During the study period, 26 cows gave birth, and of these, only $19 \%$ were of first parity. Some of the cows which did not calve during the study period had no milk recordings for more than a year. These calving intervals were much longer than indicated by the combined information about cows' age and parity numbers given by the farmers.

\section{Breeds and breeding}

Cattle were specified as local or crossbred (indigenous $x$ Holstein-Friesian of unknown percentage of genetic composition). All cows in zero-grazing system were crossbred while under tethering both local and crosses were kept. Majority of the study farms ( $87 \%$ ) used bulls for breeding and $13 \%$ of the 
Table 1 Means (and SD) and tropical livestock units (TLU) of livestock on mixed smallholder certified organic pineapple farms in tethering and zero-grazing systems

\begin{tabular}{|c|c|c|c|c|c|c|c|c|}
\hline \multirow[t]{3}{*}{ Variable } & \multicolumn{8}{|c|}{ Management systems } \\
\hline & \multicolumn{4}{|c|}{ Tethering $(n=19)$} & \multicolumn{4}{|c|}{ Zero grazing $(n=11)$} \\
\hline & Mean + SD & Median & Range & $\mathrm{TLU}^{\mathrm{a}}$ & Mean + SD & Median & Range & TLU \\
\hline \multicolumn{9}{|l|}{ Herd structure } \\
\hline Cows & $2.3 \pm 3.2$ & 1 & $1-15$ & 2.7 & $1.2 \pm 0.4$ & 1 & $1-2$ & 1.4 \\
\hline $\begin{array}{l}\text { Heifers (1 year or } \\
\text { older) }\end{array}$ & $0.3 \pm 0.6$ & 0 & $0-2$ & 0.2 & $0.2 \pm 0.4$ & 0 & $0-1$ & 0.1 \\
\hline $\begin{array}{l}\text { Female calves } \\
\quad(<1 \text { year })\end{array}$ & $1.1 \pm 1.4$ & 1 & $0-6$ & 0.3 & $0.5 \pm 0.8$ & 0 & $0-2$ & 0.2 \\
\hline $\begin{array}{l}\text { Male calves } \\
\quad(<1 \text { year })\end{array}$ & $0.8 \pm 1.0$ & 1 & $0-4$ & 0.3 & $0.8 \pm 0.6$ & 1 & $0-2$ & 0.2 \\
\hline Steers & $0.6 \pm 1.2$ & 0 & $0-4$ & 0.4 & $0.3 \pm 0.6$ & 0 & $0-2$ & 0.2 \\
\hline Bulls & $0.1 \pm 0.2$ & 0 & $0-1$ & 0.1 & $0.1 \pm 0.3$ & 0 & $0-1$ & 0.1 \\
\hline \multicolumn{9}{|c|}{ Other livestock species } \\
\hline Goats & $3.8 \pm 2.3$ & 3 & $0-8$ & 2.8 & $0.8 \pm 1.9$ & 0 & $0-6$ & 0.1 \\
\hline Chickens & $4.4 \pm 4.4$ & 5 & $0-15$ & 0.0 & $1.4 \pm 3.2$ & 0 & $0-10$ & 0.01 \\
\hline Pigs & $0.2 \pm 0.7$ & 0 & $0-3$ & 0.0 & $0.2 \pm 0.6$ & 0 & $0-2$ & 0.0 \\
\hline Sheep & $0.2 \pm 0.6$ & 0 & $0-2$ & 0.0 & - & 0 & - & 0.0 \\
\hline Ducks & $0.5 \pm 2.3$ & 0 & $0-10$ & 0.01 & - & 0 & - & 0.0 \\
\hline
\end{tabular}

${ }^{\mathrm{a}}$ Tropical livestock unit is equivalent to an animal of $250 \mathrm{~kg}$ live weight, $1 \mathrm{TLU}=1.2 \mathrm{cattle}, 0.15 \mathrm{sheep} /$ goat, 0.01 chicken and duck, 0.2 pig. Author's conversion factors are based on livestock demographic structure and mean weights of ages (Jahnke 1982) farms, all of which were zero-grazing, used artificial insemination. Farmers ranked high milk yield (score 3.0) and robustness (score 2.7) as the most important factors for breeding. None of the farms kept record on use of bulls, dates when cows were on heat and when mated.

\section{Animal housing and hygiene}

Results of on-farm observations related to hygiene and housing of cattle is presented in Table 3. Only $20 \%$ of the farms had animal housing facilities and all these were under zerograzing system. The remaining farms had their cows kept in shades of trees. The cowsheds were made of local wooden materials, which were observed to be poorly maintained. On most farms, exercise areas were soggy due to lack of drainage. Calf pens were soiled in most farms. Less than half of the farmers washed the cows' udders before milking.

\section{Outdoor access and feeding management}

Farm sizes were bigger $(P<0.05)$ in tethering system $(9.3 \pm 6.7$ acres $)$ compared to zero-grazing systems (4.3 \pm 2.6 acres $)$. In tethering system, animal were grazed with ropes tied around their neck or leg and were grazed solely on natural pastures (74 \%). Others (26\%) supplemented the pastures with crop residues
Table 2 Averages of age and parity numbers of cows on smallholder certified organic pineapple farms in tethering and zero-grazing systems

\begin{tabular}{|c|c|c|c|c|c|}
\hline \multirow[t]{3}{*}{ Variable } & \multicolumn{3}{|c|}{ Management systems } & \multirow[t]{3}{*}{ SEM } & \multirow[t]{3}{*}{$P$ value } \\
\hline & \multicolumn{2}{|c|}{ Tethering } & \multirow{2}{*}{$\begin{array}{l}\text { Zero grazing } \\
\text { Cross } \\
n=11\end{array}$} & & \\
\hline & $\begin{array}{l}\text { Cross } \\
n=12\end{array}$ & $\begin{array}{l}\text { Local } \\
n=22\end{array}$ & & & \\
\hline Age of cows (year) ${ }^{\mathrm{a}}$ & 6.0 & 6.3 & 7.3 & 0.765 & 0.247 \\
\hline Age at first calving (year) ${ }^{\mathrm{a}}$ & 3.2 & 3.1 & 1.9 & 0.135 & $<0.0001$ \\
\hline No. of parity & 2.5 & 3.6 & 4.6 & 0.546 & 0.067 \\
\hline Weaning age (months) ${ }^{\mathrm{a}}$ & 5.5 & 6.0 & 6.6 & 0.577 & 0.361 \\
\hline
\end{tabular}

${ }^{\text {a }}$ Data for these parameters of the cows expected to be in the milk recording was collected before the beginning of the longitudinal study 
Table 3 Available housing and equipment related to housing system and hygiene on smallholder certified organic pineapple farms in tethering and zero-grazing systems

\begin{tabular}{|c|c|c|c|c|c|}
\hline \multirow[t]{2}{*}{ Parameter } & \multirow[t]{2}{*}{ Observations } & \multicolumn{2}{|c|}{ Tethering $(n=19)$} & \multicolumn{2}{|c|}{$\begin{array}{l}\text { Zero grazing } \\
(n=11)\end{array}$} \\
\hline & & Number & Percent & Number & Percent \\
\hline Cow shed & & 0 & 0.0 & 6 & 54 \\
\hline Calf staying area/pen & & 16 & 84 & 11 & 100 \\
\hline Feed troughs & & 3 & 16 & 7 & 64 \\
\hline Water troughs & & 1 & 5 & 6 & 54 \\
\hline \multirow[t]{3}{*}{ Floor type in calf staying area or pen ${ }^{a}$} & Concrete floor & 1 & 6 & 4 & 36 \\
\hline & Wooden slatted floor & 0 & 0.0 & 3 & 27 \\
\hline & Earthen floor (soil) & 15 & 94 & 4 & 36 \\
\hline \multirow[t]{2}{*}{ Calf bedding } & Straw/grass & 0 & 0.0 & 1 & 9 \\
\hline & Polythene & 0 & 0.0 & 1 & 9 \\
\hline \multirow[t]{2}{*}{ Cleanliness of calf staying area or pen ${ }^{a}$} & Clean & 7 & 37 & 5 & 45 \\
\hline & Dirty & 9 & 47 & 6 & 54 \\
\hline \multirow[t]{3}{*}{ Floor type of cow Kraal/shed } & Concrete floor & 0 & 0.0 & 3 & 27 \\
\hline & Wooden slatted floor & 0 & 0.0 & 4 & 36 \\
\hline & Earthen floor (soil) & 19 & 100 & 4 & 36 \\
\hline \multirow[t]{3}{*}{ Floor type in the milking area } & Concrete floor & 0 & 0.0 & 3 & 27 \\
\hline & Wooden slatted floor & 0 & 0.0 & 1 & 9. \\
\hline & Earthen floor (soil) & 19 & 100 & 7 & 64 \\
\hline \multirow[t]{3}{*}{ Frequency of cleaning cow staying area } & More than once a day & 2 & 10 & 4 & 54 \\
\hline & Once a day & 4 & 21 & 6 & 36 \\
\hline & Once a week & 13 & 68 & 1 & 9. \\
\hline
\end{tabular}

${ }^{a}$ Three farmers in the tethering system had no separate calf staying area or pen which comprised of banana peels, sweet potato vines, pineapple wastes, maize stover, and banana pseudo stems. All zero-grazing farms provided an exercise yard so that cattle had outdoor access. Majority of the farms (82\%) used Napier grass as the basal fodder for cattle. In addition, $64 \%$ of the farms provided crop residues and maize bran as supplements.

\section{Calf management}

Majority of the farms $(87 \%)$ reared at least one calf during the study period. Farmers used an isolation calf area to restrict suckling. Seventy-seven percent of the calves were separated from the cows and only allowed suckling after morning milking. Farmers who bucket fed calves $(23 \%)$ reported $0.5-3 \mathrm{~L}$ of milk for the calf per day, depending on its age. In addition to milk, farmers provided calves with natural pastures, Napier grass, and/ or crop residues. Water was not provided to the calves ad libitum. In tethering system, $84 \%$ of the calves were weaned between 6 and 10 months compared to $91 \%$ in zero-grazing system. While $18 \%$ of the farmers used bedding materials in calf pens under zero-grazing system, none of them used it under tethering system.

\section{Daily milk recorded}

Fifty-seven percent of the cows (6 cross breed cows and 13 local breed cows) were milked twice a day and $43 \%$ of the cows once a day, in the morning or alternating from morning to evening milking in some farms. According to the milk recordings, $16 \%$ of the cows had lactations of less than 150 days; another $23 \%$ had just short milk recordings since the study had come to an end. Besides $79 \%$ of cows in the milk recordings, another $21 \%$ were present on the farm but not expected to calve during the study period and hence not included in this record. While the bulk of milk produced during the rainy and dry seasons (63-70\%) was sold to generate household income, 28-34\% was consumed at home, $2 \%$ was given to the calves, and up to $1 \%$ was given away. Milk prices ranged between 0.2 and 0.3 USD per liter in both rainy and dry season and no milk was sold as certified organic.

Mean daily milk production was higher $(P<0.05)$ for crossbred cows $(5.2 \pm 0.19 \mathrm{~L} / \mathrm{cow} /$ day $)$ compared to local breeds $(2.6 \pm 0.19 \mathrm{~L} / \mathrm{cow} /$ day) (Fig. 1). The two curves for crossbred cows showed that much of the difference in daily milk yield was due to four highest yielding cows that produced more than $10 \mathrm{~L} /$ cow/day. 
Fig. 1 Average daily milk recorded after every 2 weeks period of lactation for cross and local bred cows. "Cross" indicates milk yield of all cross bred cows. "Cross: minus 4 highest yielders" indicates recorded milk production of cross bred cows excluding the four highest yielding cows. "Local" indicates the recorded milk production of the local breeds

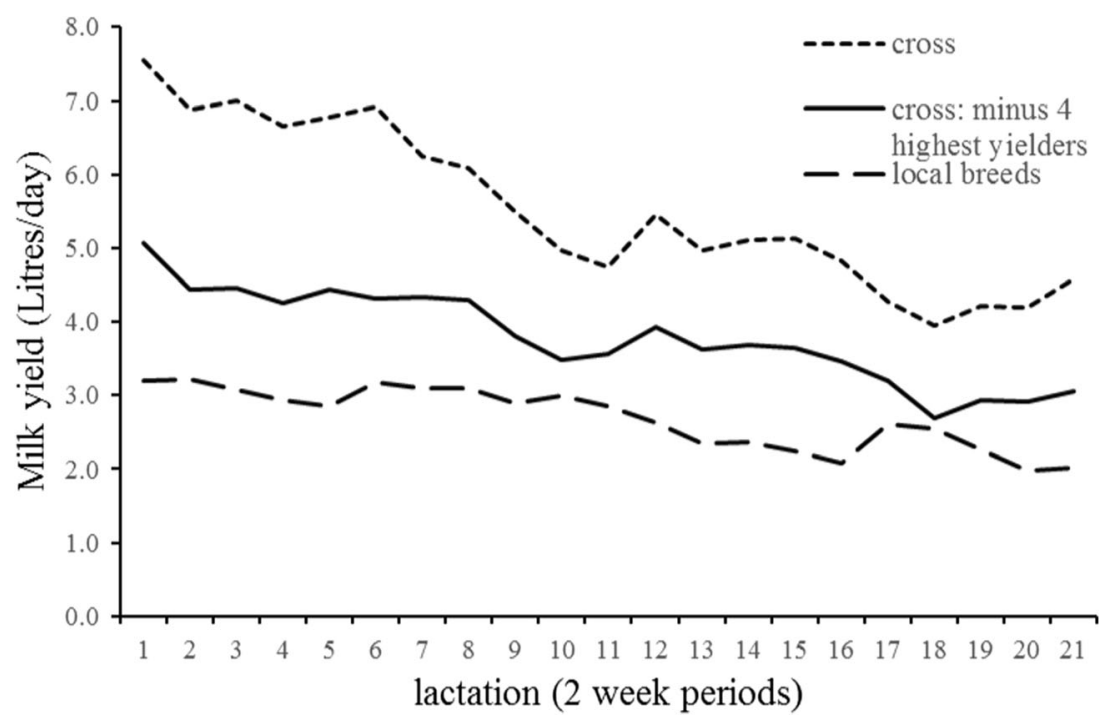

\section{Effect of management on daily milk recorded}

Although crossbred cows produced more milk than local breeds, their production varied with management system (Fig. 2). The mean daily milk production was higher $(P<0.001)$ for crossbred cows under zero-grazing system $(6.5 \pm 0.24 \mathrm{~L} / \mathrm{cow} /$ day) compared to $3.0 \pm 0.14$ from crossbred cows kept under tethering system.

\section{Effect of calving season on daily milk recorded}

Crossbred cows that calved in wet season had higher $(P<0.05)$ milk production $(6.0 \pm 0.32 \mathrm{~L} /$ cow/day $)$ compared to those that calved in the dry season $(4.2 \pm 0.32 \mathrm{~L} /$ cow/day) (Fig. 3). However, local cow breeds that calved during dry season had higher $(P<0.05)$ recorded milk production $(2.8$ $\pm 0.11 \mathrm{~L} /$ cow/day) compared to those that calved in wet season $(2.3 \pm 0.11 \mathrm{~L} /$ cow/day $)$.

\section{Diseases and parasites}

Farmers only recorded diseases treated with veterinary drugs (Table 4). The treatments were recorded on individual animal or group level. Trypanasomiasis was mostly reported on the zero-grazing farms, while helminthiasis and East Coast fever were mainly reported on tethering farms. The number of treated mastitis cases was remarkably low. Eighty-nine percent of the cases were treated by farmers themselves using chemical or herbal remedies.

\section{Farmers' strategies to animal health problems}

The study revealed that farmers used various coping strategies to handle animal health and disease-related problems. Farmers' response to an open question "What do you do to keep your animals healthy?" is summarized in Fig. 4.
Fig. 2 Average daily milk recorded after every 2 weeks period of lactation for different breed of cows in the two management systems. (Tethering indicated with a " $\mathrm{T}$ " and zero grazing indicated with a "Z")

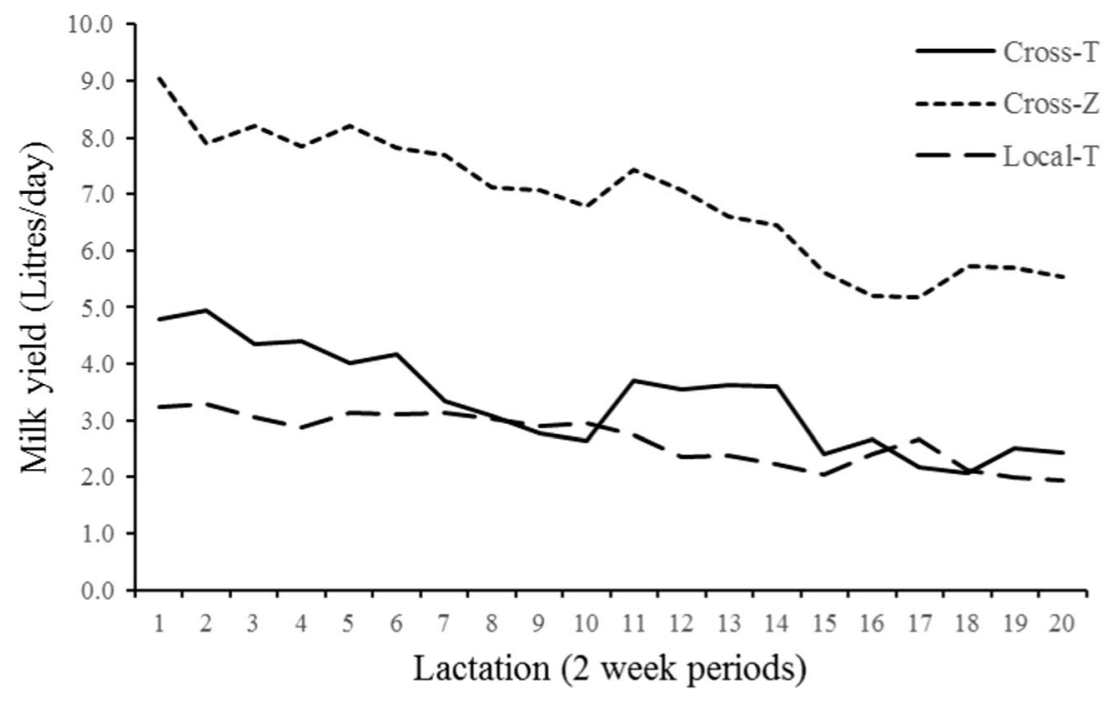


Fig. 3 Average daily milk recorded after every 2 weeks period of lactation for cows calving in dry and wet season (Crossbreed cows indicated with "c" and local bred cows "l")

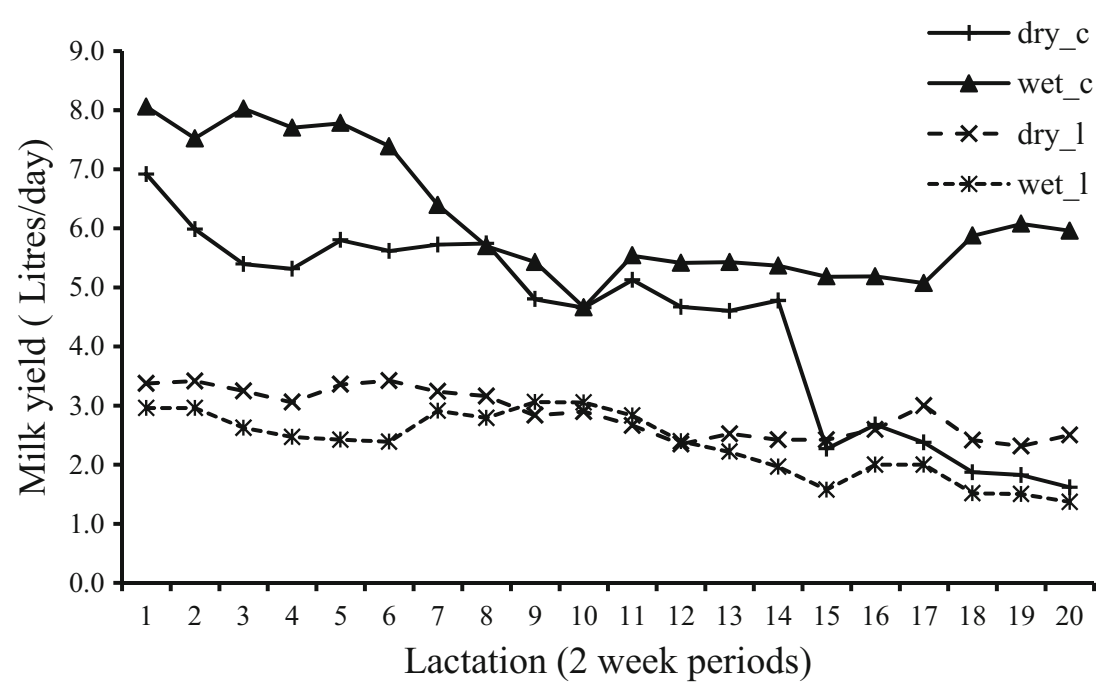

\section{Discussion}

\section{Farm structures and hygiene}

Most farms did not have housing and troughs for feed and water for the animals. In addition, the level of hygiene of both cow and calf areas was low. This is inconsistent with the East African Organic Products Standards (EAOPS) which stipulates that animals shall have living conditions that prevents abnormal behavior, injury plus disease and managed according to their natural needs (EAOPS 2007).

\section{Feeding management}

Crossbred cows kept under tethering system and fed with only natural pastures yielded less than those under zero-grazing systems. Generally, cows were fed with higher quality feeds that possibly met the cows' requirements to a higher degree. However, the major challenge with depending on natural pastures is the seasonal variation of its quality and availability
(Okello and Sabiiti 2006). The use of pastures and fresh fodder as the main feed fits well in the requirement of the EAOPS, which stipulates that diets of dairy cattle should comprise of at least $60 \%$ dry matter as organic feeds (EAOPS 2007).

\section{Grazing and outdoor access}

Since the majority of farmers under tethering system solely grazed cattle on natural pastures which is labor intensive, there could be a risk of competition between the livestock enterprise and crop production. For example, the high demands on family labor due to diversified farm enterprises, tethered cows might stay in the fields for long hours without access to water or change in grazing location. Moreover, tethering is an acceptable practice in the East African Organic Standards, but should not affect the well-being of the animals including access to adequate feed, shade, and water (EAOPS 2007). Zerograzed cows, on the other hand, were provided all the feed
Table 4 Type and number of disease treatments, number of cattle, and the number of treatments per head in tethering and zero-grazing systems during the study period

\begin{tabular}{|c|c|c|c|}
\hline \multirow[t]{2}{*}{ Type of disease } & \multirow[t]{2}{*}{ Reported symptoms } & \multicolumn{2}{|c|}{ Disease treatments } \\
\hline & & $\begin{array}{l}\text { Tethering } \\
\text { Number }\end{array}$ & $\begin{array}{l}\text { Zero grazing } \\
\text { Number }\end{array}$ \\
\hline Helminths infestation & Soft feces, potty belly, rough coat, coughing & 16 & 6 \\
\hline Trypanasomiasis & Dull skin, weight loss, loss of appetite & 2 & 6 \\
\hline East Cost fever & $\begin{array}{l}\text { Loss of appetite, fever, } \\
\text { Swollen lymph nodes, } \\
\text { Presence of ticks }\end{array}$ & 13 & 1 \\
\hline Mastitis & Swollen, hard and warm udder & 1 & 0 \\
\hline Number of cattle ${ }^{a}$ & & 96 & 34 \\
\hline Treatment per head & & 0.33 & 0.38 \\
\hline
\end{tabular}

${ }^{a}$ Number of cattle which were in the system during the study period including cows, heifers, calves, steers, and bulls 
Fig. 4 Farmers' strategies to cope with animal health problems as obtained from their response to the question "What do you do to keep your animals healthy?"

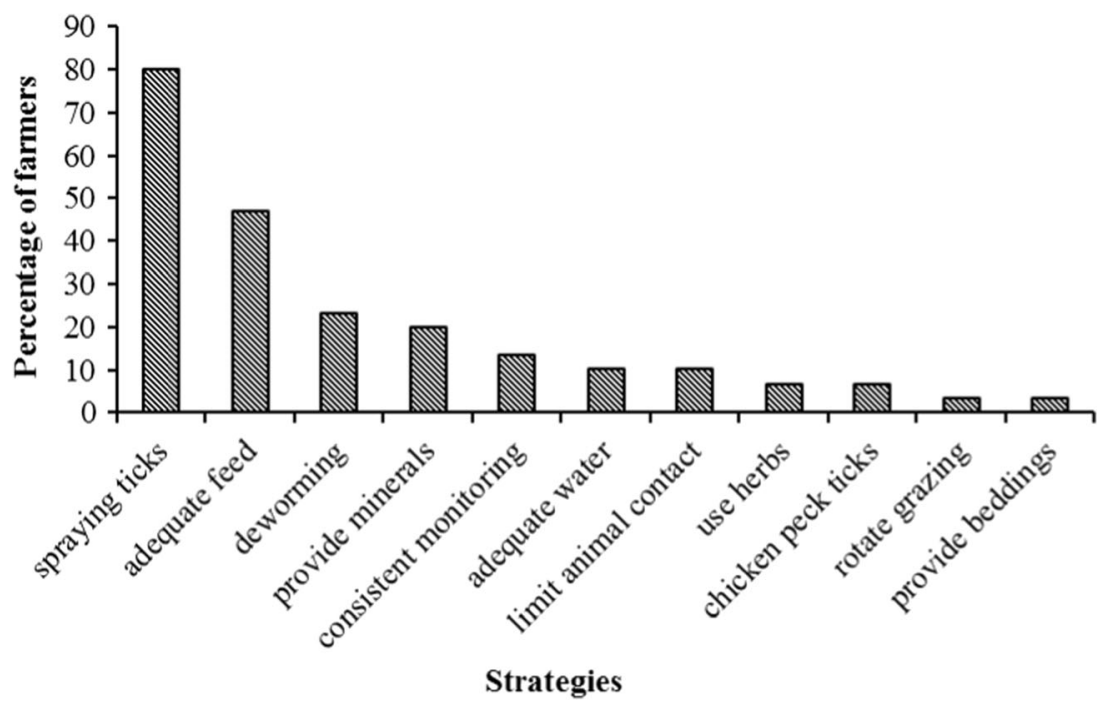

indoor but had an exercise yard to encourage outdoor access and free movement.

\section{Factors influencing milk production}

Feeding is well-known as a very influential factor for milk yield. In the study area, cattle mainly depended on natural pastures, yet in the wet season, tropical pastures grow fast and deteriorate in quality, while in the dry seasons, the decrease in pasture yields forces dairy cows to face episodes of food scarcity (Grimaud et al. 2007) when no feed has been conserved and stored. To ensure stable milk production during all seasons, farmers should ensure feed availability. This can be achieved through ensiling pineapple wastes and storing crop wastes and agro industrial by-products as supplements to the natural pastures (Negesse et al. 2009; Kiggundu 2015). This can allow cows to maintain productivity and farmers to access milk markets for the biggest part of the year.

If the farmers were able to sell milk as certified organic for a higher price, this could possibly be an incentive to prioritize higher milk production. However, low milk production per day from both crossbreds and local breeds is a major challenge which might be attributed to management. Therefore, even if the price of organic milk doubled (from 0.3 to 0.6 USD per liter), the current milk yield could still result into low profits which cannot allow farmers to access a more stable and high quality feed supply.

\section{Calf management}

Although suckling enables the cow and the calf to express natural behavior and ensures natural communication between the cow and calf (Grondahl et al. 2000; Flower and Weary 2003), restricted calf feeding was used by majority of the farmers irrespective of the system. While calves under tethering system were only allowed to suckle after morning milking, under zero-grazing system calves were bucket fed. This restriction is inconsistent with the natural living of calves recommended in organic dairy production that involves cowcalf contact and natural feeding (EAOPS 2007).

\section{Breeds and breeding}

No systematic information on breeding bulls was available for selection purposes. Therefore farmers decided which local bull to use depending on the cost and availability. This possibly influenced the length and variability of the calving intervals. Although majority of the farmers indicated high milk production as their major breeding aim, other important traits such as adaptation to local environment and utilization of available feed resources are important in meeting the health and welfare needs of the animals (Odhong et al. 2015).

\section{Disease management and health promotion strategies}

Treatment of helminths and ECF was more in the tethering system than zero-grazing system. Exposure of grazed cattle to parasites potentially increased their risk to infection. However, the low number of treatments could be attributed to efforts in controlling vectors through routine spraying, which is the main strategy used in the control of endemic vector-borne diseases in the tropics (Zilberman et al. 2011; Shaw et al. 2013). The East African Organic Standard allows for treatment using veterinary drugs; however, emphasis is on preventive measures including use of appropriate breeds, animal husbandry, and good quality feeds (EAOPS 2007).

A healthy animal is known to be incredibly resilient and has the ability to react, restore balance or homeostasis, and therefore is capable of healing itself from a range of ailments to a certain degree (Doring et al. 2015). The less than optimal 
management practices of dairy cattle in this study irrespective of management system cannot possibly allow the animals to exploit their natural potential of self-healing. Improved dairy animal health and welfare in many of the farms will require additional knowledge and capital investment. The question, however, is whether smallholder farmers are willing to invest for the long-term benefit of the animals if no immediate economic improvements are realized.

\section{Future perspectives}

Our recommendations are to (1) develop alternative feed resources for dairy cattle, (2) promote a better system of selection for local bulls for higher milk production, but taking into account trait such as adaptation to the local environment and feed resources, (3) shift the focus from disease treatment to health promotion practices, and (4) explore biorational pesticides for control and treatment of vector-borne diseases.

Acknowledgments The authors are grateful to the organic farmers who participated in the study and funds from Danish Ministry of Foreign Affairs in collaboration with International Centre for Research in Organic Food Systems, Aarhus University and Makerere University through the Productivity and Growth in Organic Value Chains (ProGroV) project.

\section{Compliance with ethical standards}

Statement of animal rights The manuscript does not contain clinical studies or patient data

Conflict of interest The authors confirm that they have no conflict of interest and no part of this is submitted anywhere else for publication.

\section{References}

Anecho, S., 2015. Understanding organic consumer characteristics in the metropolis of Kampala, Uganda. (Unpublished Msc.Thesis). Makerere University, Kampala, Uganda

Doring, T.R., Vieweger, A., Pautasso, M., Vaarst,M., Finckh, M.R., Wolfe, M.S., 2015. Resilience as a universal criterion of health. Journal of the Science of Food and Agriculture, 95: 455-465

EAOPS, 2007. East Africa Organic Product Standards. EAS 456:2007 http://www.oecd.org/aidfortrade/47719232.pdf. Accessed on 412 2015

FiBL and IFOAM., 2013. The World of Organic Agriculture 2013. Frick and Bonn. https://www.fibl.org/fileadmin/documents/shop/1606organic-world-2013.pdf. Accessed on 5122015

FIT, 2006. Fruit Sub Sector Market Study. FIT Uganda Ltd. http://www. fituganda.com/manage/download/atm/marketreports /subsectorstudyfruits.pdf. Accessed on 4122015

Flower, F. C and Weary, D. M., 2003. The effects of early separation on the dairy cow and calf. Animal Welfare, 12 (3): 339-348
Grimaud, P., Mpairwe, D., Chalimbaud, J., Messad.S., Faye,B., 2007. The place of Sanga cattle in dairy production in Uganda. Tropical Animal Health and Production (2007) 39:217-227

Grondahl, A. M., Skancke, E. M., Mejdell C. M., Jansen, J. H., 2000. Growth rate, health and welfare in a dairy herd with natural suckling until 6-8 weeks of age. Acta Veterinaria Scandinavia, 49: 16

Henning, H. J., 1998. Systems Theory as a Scientific Approach towards Organic Farming. Biological Agriculture \& Horticulture, 16:1, 37 52, DOI:10.1080/01448765.1998.9755217

Jahnke, H.E., 1982. Livestock Production Systems in Livestock Development in Tropical Africa. Kiel, FRG: Kieler Wissenschaftsverlag Vauk.

Kiggundu, M., 2015. Potential of ensiling organic pineapple by-products as dairy cattle feed on organic certified farms. (Unpublished Msc.Thesis). Makerere University, Kampala, Uganda

Kiggundu, M., Kabi, F., Vaarst, M., Nalubwama, S., Odhong, C., 2014. Management and use of dairy cattle feed resources on smallholder certified organic pineapple farms in Central Uganda. Journal of Agriculture and Environment for International Development, 108 (2): 207-225

Nalubwama, S., Vaarst, M., Kabi, F., Kiggundu, M., Bagamba, F., Odhong, C., Mugisha, A., Halberg, N., 2014. Challenges and prospects of integrating livestock into smallholder organic pineapple production in Uganda. Livestock Research for Rural Development. Volume 26, Accessed on http://www.lrrd.org/lrrd26 /6/nalu26113.htm Accessed on 11 Nov 2015

Nalubwama, S.M., Mugisha, A., Vaarst, M., 2011. Organic livestock production in Uganda: potentials, challenges and prospects. Tropical Animal Health and Production 4, 749

Negesse, T., Makka, H.P.S., Becker, K., 2009. Nutritive value of some non-conventional feed resources of Ethiopia determined by chemical analyses and an in vitro gas method. Animal Feed Science and Technology 154, 204-217

Odhong, C., Wahome, R., Vaarst,M., Kiggundu, M., Nalubwama, S., Helberg, N., Githigia,S., 2015. Dairy cattle management, health and welfare in smallholder farms: An organic farming perspective. Journal or Organics, Volume 2 Number 1

Okello, S. and Sabiiti, E.N., 2006. Milk production of indigenous Ankole cattle in Uganda as influenced by seasonal variations in temperature, rainfall and feed quality. Makerere University Research Journal, 1, 73-92

Powell, J.M., Pearson, R.A., Hiernaux, P.H., 2004. Crop-Livestock Interactions in the West African Drylands. Agronomy Journal; 97(2): 469-483

Rukundo, 2014. Uganda earns big from organic agriculture. Africa Agribusiness Magazine. http://www.africaag.org/2014/07/18 /uganda-earns-big-organic-agriculture/

Shaw, A.P.M., Torr, S.J., Waiswa, C., Cecchi, G., Wint, G.R.W., Mattioli, R.C., Robinson, T. P., 2013. Estimating the costs of tsese control options: An example for Uganda. Preventive Veterinary Medicine; 110(3-4): 290-303

Willer, H and Lernoud, J., 2015. Organic agriculture worldwide. Current statistics (FiBL), Frick, Switzerland. http://orgprints.org/28216 /7/willer-lernoud-2015-02-11-global-data.pdf. Accessed on 5 Dec 2015

Zenere, G., 2014. Agriculture in Kenya and Uganda: Relevance, Behavior and Performance. Global Majority E- Journal, Vol.5, No. 2, pp 104-116

Zilberman, D., Otte, J., Roland-Holst, D. \& Pfeiffer D., 2011. Health and Animal Agriculture in Developing Countries (Vol. 36). Springer.Zinsstag J, Schelling E, Waltner-Toews D and Tanner M, From 'one medicine' to 'one health' and systemic approaches to health and well-being. Preventive Veterinary Medicine 101:148156 